\title{
Parasitism by Sphincterodiplostomum musculosum (Digenea, Diplostomidae) metacercariae in the eyes of Steindachnerina insculpta (Characiformes, Curimatidae)
}

\author{
Parasitismo por metacercárias de Sphincterodiplostomum musculosum (Digenea, Diplostomidae) \\ nos olhos de Steindachnerina insculpta (Characiformes, Curimatidae)
}

Heleno Brandão ${ }^{1 *}$; Fábio Hideki Yamada ${ }^{1}$; Gislayne de Melo Toledo ${ }^{1}$; Aline Angelina Acosta ${ }^{1}$; Edmir Daniel Carvalho ${ }^{1}$; Reinaldo José da Silva ${ }^{1}$

${ }^{1}$ Universidade Estadual Paulista "Júlio de Mesquita Filho" - UNESP, Botucatu, SP, Brasil

Received October 27, 2013

Accepted February 17, 2014

\begin{abstract}
New occurrences and effects of parasitism by metacercariae in fish eyes have recently been discussed in many studies. The aim of the present study was to evaluate the infection levels of the eye flukes Sphincterodiplostomum musculosum Dubois, 1936 (metacercariae) in Steindachnerina insculpta (Fernádez-Yépez, 1948) from three ecosystems under the influence of the Jurumirim reservoir (Paranapanema, Taquari and Veados Rivers). A total of 174 fish specimens were sampled between April 2011 and April 2012. There were high levels of infection by S. musculosum metacercariae in the eyes of $S$. insculpta from all the sampled ecosystems, thus presenting broad geographical distribution. The histological analyses revealed that the metacercariae were apparently lodged behind the retina. The smaller fish from the Taquari River were less parasitized by metacercariae than the adults. This pattern can be explained by the cumulative effect of parasitism, as demonstrated by the positive correlation between the abundance of metacercariae and fish body size.
\end{abstract}

Keywords: Paranapanema River, freshwater fish, Steindachnerina insculpta, Brazil.

\section{Resumo}

Novas ocorrências e efeitos do parasitismo por metacercárias em olhos de peixe têm sido recentemente discutidas em muitos estudos. O objetivo deste estudo foi avaliar os níveis de infecçáo dos vermes de olho Sphincterodiplostomum musculosum Dubois, 1936 (metacercárias) em Steindachnerina insculpta (Fernádez-Yépez, 1948) de três ecossistemas influenciados pelo reservatório de Jurumirim (Rios Paranapanema, Taquari e Veados). Um total de 174 espécimes de peixes foi amostrado de Abril/2011 a Abril/2012. Metacercárias de S. musculosum mostraram altos níveis de infecção nos olhos de $S$. insculpta em todos os ecossistemas amostrados apresentando ampla distribuição geográfica. As análises histológicas revelaram que, aparentemente, estas metacercárias estavam alojadas por trás da retina. Os peixes menores do rio Taquari estavam menos parasitados por metacercárias do que os adultos. Esse padrão pode ser explicado pelo efeito cumulativo de parasitismo, evidenciado pela correlação positiva entre a abundância de metacercárias e tamanho do corpo dos peixes.

Palavras-chave: Rio Paranapanema, peixe de água doce, Steindachnerina insculpta, Brasil.

\section{Introduction}

The Neotropical region is one of the zoogeographical areas with the greatest diversity of freshwater fishes, comprising 4,000 species described (LÉVÊQUE et al., 2008). Approximately 2,587 species are found in Brazilian rivers (BUCKUP et al., 2007), however, parasitological studies have included only a small portion of this diversity (EIRAS et al., 2011). Fishes in their natural environment can present high diversity of parasites

\footnotetext{
*Corresponding author: Heleno Brandão

Universidade Estadual Paulista "Julio de Mesquita Filho" - UNESP, Distrito de

Rubiāo Junior, s/n, CEP 18618-970, Botucatu, SP, Brasil

e-mail: heleno_brandao@hotmail.com
}

with pathogenic potential, although evident clinical signs are rarely shown (BACHMANN et al., 2012). This emphasizes the importance of studies on the taxonomy and occurrences of these parasites in their host organisms.

Digenetic trematodes are parasites with heteroxenous life cycles, generally using snails as intermediate hosts and involving at least two hosts. The final host may be a fish or a piscivorous mammal or bird (THATCHER, 2006; PAVANELLI et al., 2008). Species of the Diplostomidae family have been found in fishes in Asia, Europe, North America and South America (NIEWIADOMSKA, 1996). Diplostomidae metacercariae are known as eye flukes that infect 
fish eyes, and they can be found in the retina, vitreous and aqueous humor, or crystalline lens (NIEWIADOMSKA, 1996; CHAPPELL, 1995). These digeneans may be responsible for "helminthic cataracts", also known as diplostomiasis (MARTINS et al., 1999), and in extreme cases can cause severe ocular pathology associated with blindness (CHAPPELL et al., 1994). Penetration of these parasites into different structures such as the body surface, buccal cavity and gills, and migration of the larvae to the eye, can cause injuries and hemorrhages in several tissues, thereby obstructing blood vessels. These phenomena may be associated with fish death in cases of high infection rates (VALTONEN; GIBSON, 1997).

The genus Sphincterodiplostomum Dubois, 1936, includes parasites of the intestine of neotropical birds (LUNASCHI; DRAGO, 2006). Sphincterodiplostomum is monospecific and differs from other members of the Diplostomidae family because of the presence of a dorsal tubular invagination with a sphincter at the level of the posterior testis. The original description of $S$. musculosum was based on the morphology of immature specimens collected from the intestine of an ardeid bird Agamia agami (Gmelin, 1789) in Brazil (DUBOIS, 1936, 1938).

In Brazil, metacercariae of $S$. musculosum have been reported parasitizing the eyes of Cyphocharax gilbert (Quoy and Gaimard, 1824) in Guandu River (ABDALLAH et al., 2005), Steindachnerina insculpta (Fernandez-Yépez, 1948) in the Chavantes reservoir, Middle Paranapanema River (ZAGO et al., 2013), and Hoplias malabaricus (Bloch, 1794) in the Upper Paraná River floodplain (TAKEMOTO et al., 2009). They have also been observed in the ovaries of Steindachnerina brevipinna (Eigenmann and Eigenmann, 1889) in the Rosana reservoir, Low Paranapanema River (CESCHINI et al., 2010), the gills of Prochilodus lineatus (Valenciennes, 1836) in the Upper Paraná River floodplain (LIZAMA et al., 2006) and in the visceral cavity of Hemisorubim platyrhynchos (Valenciennes, 1836) in the Upper Paraná River floodplain (GUIDELLI et al., 2003).

The aim of the present study was to evaluate the infection levels of $S$. musculosum eyeflukes in $S$. insculpta from three areas under the influence of the Jurumirim reservoir, thus contributing to the knowledge of the geographical distribution and occurrence of digenetic helminths in Neotropical fishes. Our prediction was that the levels of infection of S. musculosum in S. insculpta would not differ among the ecosystems sampled.

\section{Materials and Methods}

The Jurumirim reservoir $\left(23^{\circ} 12^{\prime} 17^{\prime \prime} \mathrm{S}, 49^{\circ} 13^{\prime} 19^{\prime \prime} \mathrm{W}\right)$ is the uppermost reservoir in a cascade system in the Paranapanema River and is operated as a regulator for the other ones further downstream. It is of storage type, with an approximate area of $440 \mathrm{~km}^{2}$ (HENRY et al., 2006). The tributaries sampled were the Taquari River (2329'21.95”S, 49¹2'6.90”W), Veados River (2315'42.4”, 48³7'27.6”W) and Paranapanema River (2315'11.9”'S, 49¹2'34.2”W).

Steindachnerina insculpta belongs to the Curimatidae family and is widely distributed in South America (REIS et al., 2003). The hosts were caught quarterly from April 2011 to April 2012 using gillnets of different mesh sizes with standardized effort.
The individuals sampled were measured (standard length to the nearest $0.1 \mathrm{~cm}$ ) and weighed (nearest $0.1 \mathrm{~g}$ ).

The helminths were fixed under coverslip pressure in AFA solution (alcohol, formalin and acetic acid), preserved in 70\% alcohol, stained in Mayer's carmalum, cleared in creosote and mounted in Canada balsam (EIRAS et al., 2006). The morphometric analyses were performed using a computerized image analysis system (LAS, Leica Microsystems, Wetzlar, Germany). The morphometric results (in micrometers) are presented as mean (minimum-maximum) values. Voucher specimens of the parasites were deposited in the Helminthological Collection of the Institute of Biosciences (Coleção Helmintológica do Instituto de Biociências, CHIBB), UNESP, Botucatu, state of São Paulo, Brazil.

The eyes of two specimens of $S$. insculpta sampled in the Taquari River were histologically analyzed, with the aim of determining the infection site of the metacercariae. The eyes were carefully removed, fixed with $4 \%$ formaldehyde for at least 24 hours, dehydrated in progressive ethanol solutions (70\% to $95 \%)$ and impregnated with Historesin for 24 hours. The material was then sectioned at the thickness of $5 \mu \mathrm{m}$ using a rotating microtome equipped with a glass blade, and stained with hematoxylin and eosin.

In accordance with Bush et al. (1997), the following community descriptors were calculated at the infra community level: prevalence (\%), mean intensity of infection and mean abundance.

To determine the metacercariae distribution in the host population, three size classes were separated based on the length of the fish sampled, as follows: Class I (up to $5.3 \mathrm{~cm}$ ), Class II (from 5.4 to $6.9 \mathrm{~cm}$ ) and Class III (greater than $7 \mathrm{~cm}$ ). Individuals belonging to Class I and Class II were sampled only in the Taquari River. The prevalence of the three classes was compared using the $\mathrm{Z}$ test, and the significance level used was $p<0.05$.

Statistical differences in parasite abundance among the three rivers studied were tested using Kruskal-Wallis variance analysis (ZAR, 1996) only for individuals belonging to class III. Spearman's rank correlation (rs) was used to investigate the length and weight relationship of the host, and the abundance of eye flukes in the fish population of the Taquari River (ZAR, 1996).

\section{Results}

A total of 174 specimens of $S$. insculpta were sampled: 95 in the Taquari River, 42 in the Paranapanema River and 37 in the Veados River. Sphincterodiplostomum musculosum was present in all samples belonging to Class III (prevalence $=100 \%$ ), and for classes I and II in the Taquari River, the prevalences were 9.1 and 53.8 respectively (Table 1 ). There was a positive correlation between the abundance of metacercariae of $S$. musculosum and the length (Figure 1) and weight (Figure 2) of the host population sampled in the Taquari River.

The comparisons of prevalences among the three classes were significant for samples from the Taquari River (I versus II, $\mathrm{Z}=2.489 ; \mathrm{p}=0.013$ ) (II versus $\mathrm{III}, \mathrm{Z}=4.675 ; \mathrm{p}=0.001$ ) (I versus III, $Z=8.036 ; \mathrm{p}=0.001)$. The abundances of $S$. musculosum in the eyes of $S$. insculpta among the three tributaries were similar (Kruskal-Wallis, $\mathrm{H}=0.2 ; \mathrm{p}=0.9$ ). 
Table 1. Data on infection by metacercariae of Sphincterodiplostomum musculosum in the eyes of Steindachnerina insculpta sampled in the tributaries of the Jurumirim reservoir, Brazil. Sampled hosts $(\mathrm{N})$, mean length \pm standard error $(\mathrm{ML} \pm \mathrm{SE})$, mean weight \pm standard error $(\mathrm{MW} \pm \mathrm{SE})$, prevalence $(\mathrm{P} \%)$, mean abundance \pm standard error $(\mathrm{MA} \pm \mathrm{SE})$, mean intensity \pm standard error $(\mathrm{MI} \pm \mathrm{SE})$ and range $(\mathrm{RA})$.

\begin{tabular}{lccccc}
\hline $\begin{array}{l}\text { Ecological } \\
\text { descriptors }\end{array}$ & \multicolumn{3}{c}{ Taquari } & Paranapanema & Veados \\
\cline { 2 - 6 } Class I & Class II & Class III & 60 & 42 & Class III \\
N & 22 & 13 & $9.8 \pm 0.1$ & $8.9 \pm 0.7$ & $9.7 \pm 0.1$ \\
ML \pm SE & $4.0 \pm 0.1$ & $6.2 \pm 0.1$ & $25.8 \pm 1.1$ & $17.2 \pm 0.5$ & $20.8 \pm 0.1$ \\
PW \pm SE & $1.7 \pm 0.2$ & $6.1 \pm 0.2$ & 100 & 100 & 100 \\
MA \pm SE & 9.1 & 53.8 & $41.5 \pm 7.1$ & $35.3 \pm 5.5$ & $39.2 \pm 9.8$ \\
MI \pm SE & $0.2 \pm 0.19$ & $1.7 \pm 0.7$ & $41.5 \pm 7.1$ & $35.3 \pm 5.5$ & $39.2 \pm 9.8$ \\
RA & $3 \pm 1$ & $3.6 \pm 1.1$ & $(1-286)$ & $(2-119)$ & $(1-337)$ \\
\hline
\end{tabular}

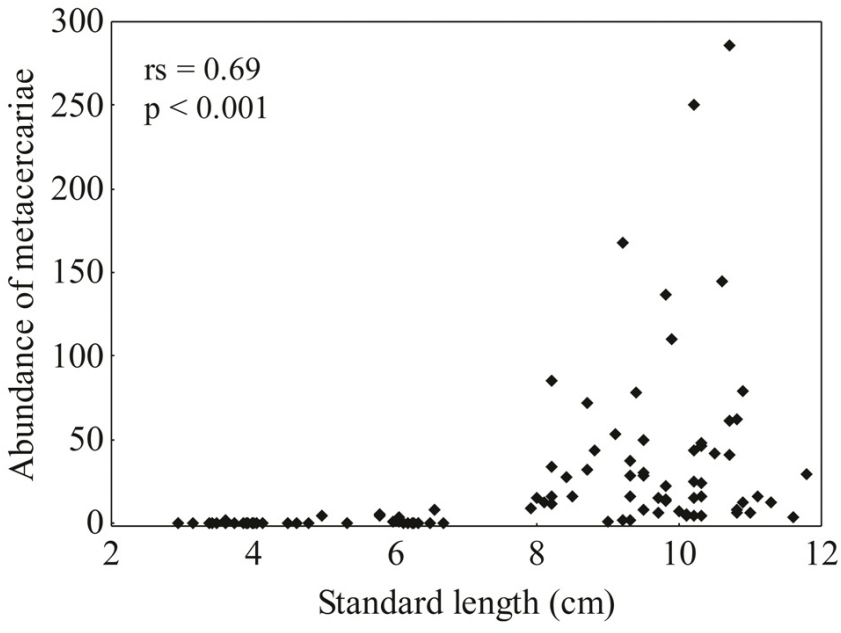

Figure 1. Correlation between the standard length of Steindachnerina insculpta (Fernández-Yépez, 1948) and abundance of metacercariae of Sphincterodiplostomum musculosum Dubois, 1936, in the Taquari River, Upper Paranapanema River, Brazil.

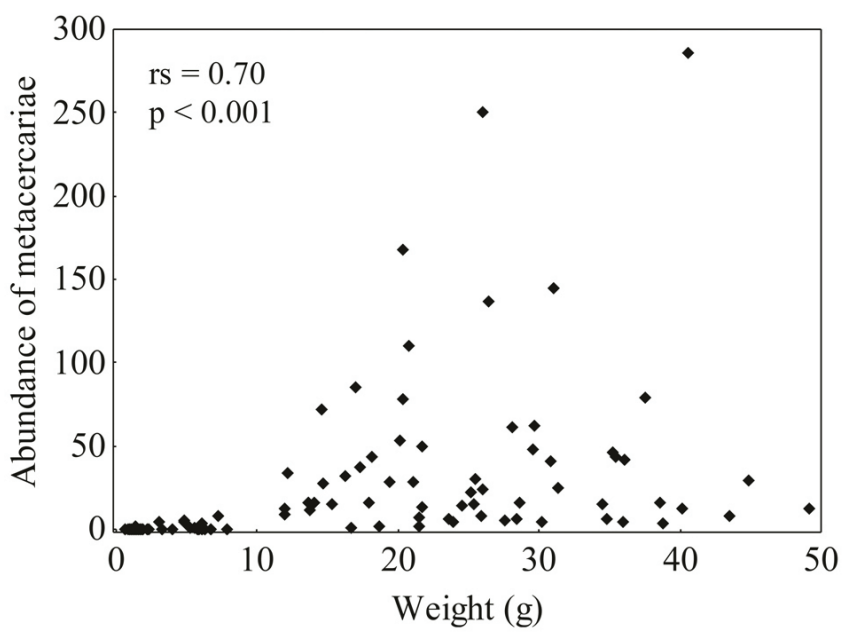

Figure 2. Correlation between the weight of Steindachnerina insculpta (Fernández-Yépez, 1948) and abundance of metacercariae of Sphincterodiplostomum musculosum Dubois, 1936, in the Taquari River, Upper Paranapanema River, Brazil.
The morphometric data on the metacercariae of $S$. musculosum and comparisons with the literature are summarized in Table 2. The histological analysis revealed that the parasites are apparently lodged behind the retina, next to the optical nerve (Figure 3).

\section{Discussion}

This study reports occurrences of metacercariae of the eye fluke $S$. musculosum in $S$. insculpta in the Paranapanema, Taquari and Veados rivers, Upper Paranapanema River. Adult forms of this helminth parasitize birds (LUNASCHI; DRAGO, 2006), and the larval forms are found in two hosts (snails and fishes). Metacercariae can infect almost all the organs or tissues of fishes (EIRAS et al., 2010).

The comparison of morphometric data of S. musculosum metacercariae parasitizing host populations from other localities (S. insculpta in the Chavantes reservoir, Middle Paranapanema River, and $S$. brevipinna in the Rosana reservoir, Lower Paranapanema River) revealed similar sizes. These results may be explained by the fact that even though these host populations are from different locations, they dwell in the same ecosystem or water body (Paranapanema River). However, several factors may act to produce significant variations in body dimensions of metacercariae, such as host species, host size and age, population size associated with intensity-dependent growth, worm condition at fixation and fixation technique (BROWN et al., 2003; FREDENSBORG; POULIN, 2005; SALDANHA et al., 2009; CHAPPELL, 1995).

Regarding comparisons of morphometric data with the literature, this study showed that the values for 'anterior testis length' were not similar to the values found by Ceschini et al. (2010) and Zago et al. (2013). The metacercariae of $S$. musculosum present two testes: the shape of the anterior testis resembles a 'walking stick' while the posterior testis is shaped like the letter ' $U$ ' upside-down; the two testes overlap and are located in the middle portion of the metacercarial hindbody (Figure 4). This disposition was represented in a line drawing by Ceschini et al. (2010), in which the shapes of the testes are very clear. However, the morphometric differences in the length of the anterior testis shown in the present study may be due to the fact that Ceschini et al. (2010) and Zago et al. (2013) used the measurements of the first portion of the anterior testis, as checked in the specimens of this study (Table 2). Furthermore, 
Table 2. Comparative morphometric data (mean and range in micrometers) of Sphincterodiplostomum musculosum metacercariae between the present study and Ceschini et al. (2010) and Zago et al. (2013).

\begin{tabular}{|c|c|c|c|}
\hline \multirow{3}{*}{$\begin{array}{c}\text { S. musculosum mea- } \\
\text { surements }(\mathrm{CHIBB} \\
7179)\end{array}$} & Present study & Ceschini et al. (2010) & Zago et al. (2013) \\
\hline & Steindachnerina insculpta & Steindachnerina brevipinna & Steindachnerina insculpta \\
\hline & $\mathrm{N}=\mathbf{3 0}$ & $\mathrm{N}=15$ & $\mathbf{N}=30$ \\
\hline Locality & $\begin{array}{l}\text { Jurumirim reservoir, Upper } \\
\text { Paranapanema River }\end{array}$ & $\begin{array}{l}\text { Rosana reservoir, Low } \\
\text { Paranapanema River }\end{array}$ & $\begin{array}{c}\text { Chavantes reservoir, Middle } \\
\text { Paranapanema River }\end{array}$ \\
\hline \multicolumn{4}{|l|}{ Body } \\
\hline Length & $2818.2(1973.9-3630.5)$ & $2553(1775-3075)$ & $2734(2151-3982)$ \\
\hline Width & $1435.6(999-1775.6)$ & $1396(1075-1675)$ & $1272.4(914.4-1844.3)$ \\
\hline \multicolumn{4}{|l|}{ Forebody } \\
\hline Length & $1682.9(1241.5-2249.8)$ & $1530(1150-1900)$ & $1642.6(1133.9-2346.9)$ \\
\hline Width & $1435.6(999-1775.6)$ & $1508(1075-1675)$ & $1272.4(914.4-1844.3)$ \\
\hline \multicolumn{4}{|l|}{ Hindbody } \\
\hline Length & $1114(734.5-1462.8)$ & $1033(600-1375)$ & $1087.4(810.9-1811.1)$ \\
\hline Width & $645.6(502.9-750.4)$ & $665(500-800)$ & $572.8(452.8-745.4)$ \\
\hline \multicolumn{4}{|l|}{ Pharynx } \\
\hline Length & $107(72-104)$ & $104(84-117)$ & $114.8(89.6-218.5)$ \\
\hline Width & $70.6(42.9-178.8)$ & $54(45-84)$ & $73.1(47.9-113.4)$ \\
\hline \multicolumn{4}{|l|}{ Oral sucker } \\
\hline Length & $137.2(80.7-167.4)$ & $145(100-200)$ & $142.4(96.3-292.6)$ \\
\hline Width & $169.7(115.1-173.5)$ & $213(130-200)$ & $180.5(134.8-313.6)$ \\
\hline \multicolumn{4}{|l|}{ Pseudosuckers } \\
\hline Length & $223.8(159.5-342.3)$ & - & $216.4(161.5-475.9)$ \\
\hline Width & $251.1(212.2-342.5)$ & - & $261.1(186.8-438.4)$ \\
\hline \multicolumn{4}{|l|}{ Ventral sucker } \\
\hline Length & $181.1(120.9-217.3)$ & $162(130-210)$ & $142.4(96.3-292.6)$ \\
\hline Width & $224.4(192.3-256)$ & $213(180-250)$ & $180.5(134.8-313.6)$ \\
\hline \multicolumn{4}{|l|}{ Tribocytic organ } \\
\hline Length & $404.8(210.2-604.9)$ & $384(290-440)$ & $391.5(246-644.6)$ \\
\hline Width & $444.5(287.9-573.6)$ & $490(350-650)$ & $494.9(321.2-732.4)$ \\
\hline \multicolumn{4}{|l|}{ Anterior testis } \\
\hline First portion length & $275(144.7-414)$ & - & - \\
\hline Length & $485.7(262.7-717.4)$ & $217(130-390)$ & $285.4(199.8-452.7)$ \\
\hline Width & $332.4(267-433.2)$ & $307(250-350)$ & $293.2(209.4-414.3)$ \\
\hline \multicolumn{4}{|l|}{ Posterior testis } \\
\hline Length & $284.8(156.9-469.6)$ & $290(210-400)$ & $310.1(210-446.6)$ \\
\hline Width & $448.9(315.4-525.9)$ & $410(200-510)$ & $385.1(275.2-557.9)$ \\
\hline \multicolumn{4}{|l|}{ Ovary } \\
\hline Length & $75.5(59.3-99.7)$ & - & - \\
\hline Width & $95.9(66.2-135.8)$ & - & - \\
\hline
\end{tabular}

this study provides complementary data on the measurements of the ovary, which had not been shown before.

The occurrence of high numbers of parasites in the eye of S. insculpta (per host), indicates that metacercariae of $S$. musculosum are well adapted to this host. Zago et al. (2013) also suggested that $S$. insculpta is highly susceptible to infection by this parasite. Moreover, we raise the hypothesis that higher average temperature is an important factor for high levels of infection in the population of S. insculpta in the Jurumirim reservoir, Paranapanema River. The Jurumirim reservoir presents a mean temperature of $22.8^{\circ} \mathrm{C}$ (range 20.9 to $24.9^{\circ} \mathrm{C}$ ) (GRANADO; HENRY, 2012). According to Valtonen and Gibson (1997), transmission and production of cercariae is primarily regulated by temperature. Cercariae of species of the genus Diplostumum emerge into the water only at temperatures above $10{ }^{\circ} \mathrm{C}$ (BERRIE, 1960; WOOTTEN, 1974; BRASSARD et al., 1982; STABLES; CHAPPELL, 1986). Moreover, the optimum temperature for the establishment of metacercariae is $17.5^{\circ} \mathrm{C}$ (STABLES; CHAPPELL, 1986).

During ontogeny, changes to the behavior and biology of fish occur (TAKEMOTO et al., 1996). Changes to the diet can include a large number of items used in the life cycle of parasites, such as intermediate hosts or even aquatic plants containing parasite structures (larvae and eggs), resulting in higher parasite abundance in larger fishes. It is expected that parasites cause low damage to the host, and thus the fish can increase in size and weight regardless of parasitism, and harbor a larger quantity of parasites (POULIN, 1998). In this study, the levels of infection by metacercariae of $S$. musculosum in $S$. insculpta (size class III) 


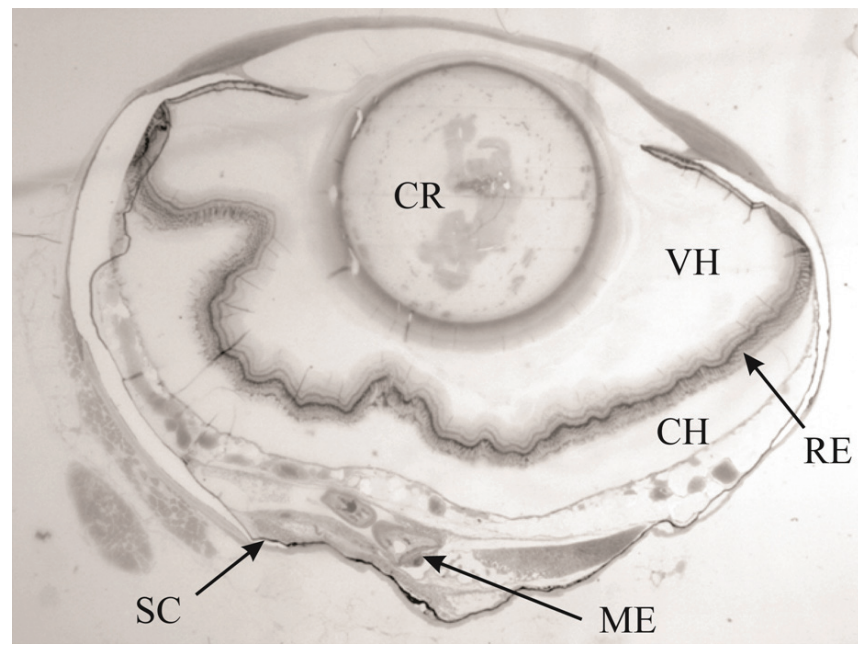

Figure 3. Histological section of the eye of Steindachnerina insculpta (Fernández-Yépez, 1948) and site of infection of Sphincterodiplostomum musculosum Dubois, 1936, metacercaria. $\mathrm{CR}=$ crystalline lens; $\mathrm{VH}=$ vitreous humor; $\mathrm{RE}=$ retina; $\mathrm{CH}=$ choroid $\mathrm{ME}=$ metacercariae; $\mathrm{SC}=$ sclera.

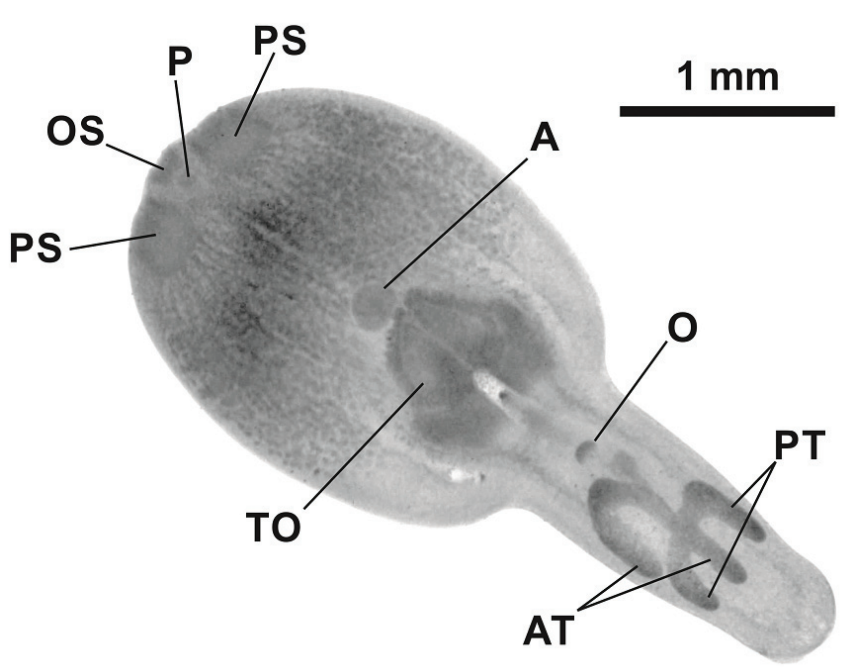

Figure 4. Specimen of Sphincterodiplostomum musculosum Dubois, 1936, metacercaria in the eye of Steindachnerina insculpta (FernándezYépez, 1948). Note the morphology and disposition of anterior (AT) and posterior (PT) testes. PS = pseudo suckers; $\mathrm{P}=$ pharynx; $\mathrm{OS}=$ oral sucker; $\mathrm{A}=$ acetabulum (ventral sucker); $\mathrm{TO}=$ tribocytic organ; $\mathrm{O}=$ ovary. Scale bar $=1 \mathrm{~mm}$.

from the three localities did not show differences. Smaller hosts collected in the Taquari River showed lower levels of parasitism, compared with larger hosts. In this case, a significant positive correlation between the standard length and weight of the host and the abundance may occur as a result from the temporal accumulation process (YAMADA et al., 2012), i.e. the length of exposure of $S$. insculpta to metacercariae of $S$. musculosum.

Digenean trematodes have a complex life cycle in which at least three hosts are involved. The second stage (cercaria) infects the second intermediate fish host, in elevated numbers, usually through the gills, and develops an unencysted larva (metacercaria).
Metacercariae of Diplostomidae infecting fish eyes are usually found in the retina, vitreous humor, aqueous humor and/or crystalline lens (YAMADA et al., 2008; ZICA et al., 2009) and they can be easily observed with the aid of a stereomicroscope or even with the naked eye. In one histological section of the present study, metacercariae of $S$. musculosum were observed lodged behind the retina. Nonetheless, further studies are necessary in order to be sure that the site of infection of $S$. musculosum differs from that of other eye flukes.

There are gaps in the knowledge of the life cycle of these parasites that might be fully understood based on studies on the helminth fauna of piscivorous birds. Thus, it is possible that metacercariae of S. musculosum use $S$. insculpta and $S$. brevipinna, which are both abundant in the Paranapanema River, as intermediate hosts in order to reach the maximum biotic potential, and complete their life cycle in ardeid birds, which are common in South America. Therefore, future studies on the helminth fauna of birds are suggested in order to better understand the life cycle of this parasite.

\section{Acknowledgements}

The authors thank the Coordenação de Aperfeiçoamento Pessoal de Nivel Superior (CAPES) (AUX-PE-PNPD 3005/2010) and Fundação de Amparo a Pesquisa do Estado de São Paulo, (FAPESP) (2011/22603-3) for the scholarships granted, and the latter for the financial support (2010/19543-6); the staff of the Fish Biology and Ecology Laboratory and the Wild Animal Parasitology Laboratory, Botucatu Institute of Biosciences; and Universidade Estadual Paulista for the structure offered for developing this study.

\section{References}

Abdallah VD, Azevedo RK, Luque JL. Ecologia da comunidade de metazoários parasitos do sairú Cyphocharax gilbert (Quoy e Gaimard, 1824) (Characiformes: Curimatidae) do rio Guandu, estado do Rio de Janeiro, Brasil. Rev Bras Parasitol Vet 2005; 14(4): 154-159. PMid:16445872.

Bachmann F, Jerônimo GT, Junior AAS, Bertelli PW, Greinert-Goulart JA, Martins ML. Parasitofauna e hematologia de Pimelodus maculatus Lacépède, 1803 (Osteichthyes: Pimelodidae) do rio Itajaí Açu, Blumenau, Brasil. In: Souza-Silva AT, Lizama MAP, Takemoto RM. Patologia e sanidade de organismos aquáticos. Maringá: Editora Masson; 2012. p. 81-104.

Berrie AD. Two Diplostomulum larvae (Strigeida, Trematoda) in the eyes of sticklebacks (Gasterostens aculeatus L.). J Helminthol 1960; 34(3-4): 211 216. http://dx.doi.org/10.1017/S0022149X00021143

Brassard P, Curtis MA, Rau ME. Seasonality of Diplostomum spathaceum (Trematoda: Strigeidae) transmission to brook trout (Salvelinus fontinalis) in northern Quebec, Canada. Can J Zool 1982; 60(10): 2258-2263. http://dx.doi.org/10.1139/z82-291

Brown SP, De Lorgeril J, Joly C, Thomas F. Field evidence for densitydependent effects in the trematode Microphallus papillorobustus in its manipulated host, Gammarus insensibilis. J Parasitol 2003; 89(4): 668672. PMid:14533671. http://dx.doi.org/10.1645/GE-3122

Buckup PA, Menezes NA, Ghazzi MSA. Catálogo das espécies de peixes de água doce do Brasil. Rio de Janeiro: Museu Nacional; 2007. 195 p. 
Bush AO, Lafferty KD, Lotz JM, Shostak AW. Parasitology meets ecology on its own terms: Margolis et al. revisited. J Parasitol 1997; 83(4): 575583. PMid:9267395. http://dx.doi.org/10.2307/3284227

Ceschini TL, Takemoto RM, Yamada FH, Moreira LHA, Pavanelli GC. Endoparasites of Steindachinerina brevipinna (Eigenmann and Eigenmann, 1889), collected in the tributaries Corvo and Guairacá of Paranapanema river, Paraná State, Brazil. Acta Sci Biol Sci 2010; 32(2): 125130. http://dx.doi.org/10.4025/actascibiolsci.v32i2.4102

Chappell LH, Hardie LJ, Secombes CJ. Diplostomiasis: the disease and host-parasite interactions. In: Pike AW, Lewis JW. Parasitic diseases of fish. Dyfed: Samara Publishing; 1994. p. 59-86.

Chappell LH. The biology of diplostomatid eyeflukes of fishes. $J$ Helminthol 1995; 69(2): 97-101. PMid:7636163. http://dx.doi. org/10.1017/S0022149X00013961

Dubois G. Monographie des Strigeida (Trematoda). Mém Soc Neuchâtel des Sci Nat 1938; 6: 1-535.

Dubois G. Nouveaux principes de classification des Trématodes du groupe des Strigeida (notes préliminaire). Rev Suisse Zool 1936; 43(3): 507-515.

Eiras JC, Takemoto RM, Pavanelli GC, Adriano EA. About the biodiversity of parasites of freshwater fish from Brazil. Bull Eur Ass Fish Pathol 2011; 31(4): 161-168.

Eiras JC, Takemoto RM, Pavanelli GC. Diversidade dos parasitas de peixes de água doce do Brasil. Maringá: Clichetec; 2010. 333 p.

Eiras JC, Takemoto RM, Pavanelli GC. Métodos de estudo e técnicas laboratoriais em parasitologia de peixes. 3th ed. Maringá: Eduem; 2006.

Fredensborg BL, Poulin R. Larval helminths in intermediate hosts: does competition early in life determine the fitness of adult parasites? Int $\mathrm{J}$ Parasitol 2005; 35(10): 1061-1070. PMid:16019005. http://dx.doi. org/10.1016/j.ijpara.2005.05.005

Granado DC, Henry R. Changes in abiotic characteristics of water in the Paranapanema River and three lateral lagoons at mouth zone of the Jurumirim Reservoir during the flood period, São Paulo, Brazil. Lat Am J Aquat Res 2012; 40(1): 79-89. http://dx.doi.org/10.3856/vol40issue1-fulltext-8

Guidelli GM, Isaac A, Takemoto RM, Pavanelli GC. Endoparasite infracommunities of Hemisorubim platyrhynchos (Valenciennes, 1840) (Pisces: Pimelodidae) of the Baía river, upper Paraná river floodplain, Brazil: Specific composition and ecological aspects. Braz J Biol2003; 63(2): 261-268. PMid:14509848. http://dx.doi.org/10.1590/ S1519-69842003000200011

Henry R, Nogueira MG, Pompêo MLM, Moschini-Carlos V. Annual and short-term variability in primary productivity by phytoplankton and correlated abiotic factors in the Jurumirim Reservoir (São Paulo, Brazil). Braz J Biol 2006; 66(1B): 239-261. PMid:16710518. http:// dx.doi.org/10.1590/S1519-69842006000200008

Lévêque C, Oberdorff T, Paugy D, Stiassny MLJ, Tedesco PA. Global diversity of fish (Pisces) in freshwater. Hydrobiologia 2008; 595: 545-567. http://dx.doi.org/10.1007/s10750-007-9034-0

Lizama MAP, Takemoto RM, Pavanelli GC. Parasitism influence on the hepato, splenosomatic and weight/length relation and relative condition factor of Prochilodus lineatus (Valenciennes, 1836) (Prochilodontidae) of the Upper Paraná River Floodplain, Brazil. Rev Bras Parasitol Vet 2006; 15(3): 116-122.

Lunaschi LI, Drago FB. First report of adult specimens of Sphincterodiplostomum musculosum (Digenea, Diplostomidae). Parasitol Int 2006; 55(1): 7-10. PMid:16126453. http://dx.doi.org/10.1016/j. parint.2005.07.002
Martins ML, Fujimoto RY, Nascimento AA, Moraes FR. Ocorrência de Diplostomum sp. Nordmann, 1832 (Digenea: Diplostomatidae) em Plagioscion squamosissimus Heckel, 1840, proveniente do reservatório de Volta Grande, MG, Brasil. Acta Sci Biol Sci 1999; 21(2): 263-266.

Niewiadomska K. The genus Diplostomum - taxonomy, morphology and biology. Acta Parasitol 1996; 41(2): 55-66.

Pavanelli GC, Eiras JC, Takemoto RM. Doenças de peixes: profilaxia, diagnóstico e tratamento. Maringá: Eduem; 2008. 311 p.

Poulin R. Evolutionary ecology of parasites: from individuals to communities. London, UK: Chapman \& Hall; 1998.

Reis RE, Kullander SO, Ferraris CJ Jr. Check list of the freshwater fishes of South and Central America. Porto Alegre: EDIPUCRS; 2003.

Saldanha I, Leung TLF, Poulin R. Causes of intraspecific variation in body size among trematode metacercariae. J Helminthol 2009; 83(3): 289-293. PMid:19216824. http://dx.doi.org/10.1017/S0022149X09224175

Stables JN, Chappell LH. The epidemiology of diplostomiasis in farmed rainbow trout from north-east Scotland. Parasitology 1986; 92(Pt 3): 699710. PMid:3737248. http://dx.doi.org/10.1017/S0031182000065550

Takemoto RM, Amato JFR, Luque JL. Comparative analysis of the metazoan parasite communities of leatherjackets, Oligoplites palometa, $O$. saurus, and O. saliens (Osteichthyes: Carangidae) from Sepetiba Bay, Rio de Janeiro, Brazil. Braz J Biol 1996; 56(4): 639-650.

Takemoto RM, Pavanelli GC, Lizama MAP, Lacerda ACF, Yamada FH, Moreira LHA, et al. Diversity of parasites of fish from the Upper Paraná River floodplain, Brazil. Braz J Biol 2009; 69(S2): 691-705. PMid:19738975. http://dx.doi.org/10.1590/S1519-69842009000300023

Thatcher VE. Amazon fish parasites. 2nd ed. Sofia: Pensoft; 2006.508 p.

Valtonen ET, Gibson DI. Aspects of the biology of diplostomid metacercarial (Digenea) populations occurring in fishes in different localities of northern Finland. Ann Zool Fenn 1997; 34(1): 47-59.

Wootten R. Observations on strigeid metacercariae in the eyes of fish from Hanningfield Reservoir, Essex, England. J Helminthol 1974; 48(1): 73-83. PMid:4825437. http://dx.doi.org/10.1017/S0022149X00022628

Yamada FH, Moreira LHA, Ceschini TL, Lizama MAP, Takemoto RM, Pavanelli GC. Parasitism associated with length and gonadal maturity stage of the freshwater fish Metynnis lippincottianus (Characidae). Neotrop Helminthol 2012; 6(2): 247-253.

Yamada FH, Moreira LHA, Ceschini TL, Takemoto RM, Pavanelli GC. Novas ocorrências de metacercária de Austrodiplostomum compactum (Lutz, 1928) (Platyhelminthes: Digenea) parasito de olhos de peixes da bacia do rio Paraná. Rev Bras Parasitol Vet 2008; 17(3): 163-166. PMid:19245765. http://dx.doi.org/10.1590/ S1984-29612008000300010

Zago AC, Franceschini L, Ramos IP, Zica EOP, Wunderlich AC, Carvalho ED, et al. Sphincterodiplostomum musculosum (Digenea, Diplostomidae) infecting Steindachnerina insculpta (Characiformes, Curimatidae) in the Chavantes Reservoir, Southeastern Brazil. Rev Bras Parasitol Vet 2013; 22(1): 98-103. PMid:24252954. http://dx.doi.org/10.1590/ S1984-29612013000100018

Zar JH. Bioestatistical analysis. 3rd ed. New Jersey: Prentice Hall; 1996.

Zica EOP, Santos KR, Ramos IP, Zanatta AS, Carvalho ED, Silva RJ. First case of an infection of the metacercariae of Austrodiplostomum compactum (Lutz, 1928) (Digenea, Diplostomidae) in Hypostomus regani (Ihering, 1905) (Siluriformes: Loricariidae). Pan-Am J Aquat Sci 2009; 4(1): 35-38. 